\title{
The Role of External Public Audit in Ensuring the Financial Stability of the Budgets of Developing Countries
}

\author{
Eldar B. Karabayev \\ L.N. Gumilyov Eurasian National University \\ 010008, 2 Satpayev Str., Nur-Sultan, Republic of Kazakhstan \\ Lyazzat M. Sembiyeva \\ L.N. Gumilyov Eurasian National University \\ 010008, 2 Satpayev Str., Nur-Sultan, Republic of Kazakhstan \\ South Ural State University \\ 454080, 76 Lenin Ave., Chelyabinsk, Russian Federation
}

\author{
Altai B. Zeinelgabdin \\ Academy of Public Administration under the President of the Republic of Kazakhstan \\ 010000, 33 a Abay Ave., Nur-Sultan, Republic of Kazakhstan \\ Lyazzat Z. Beisenova \\ L.N. Gumilyov Eurasian National University \\ 010008, 2 Satpayev Str., Nur-Sultan, Republic of Kazakhstan \\ Dzmitry A. Pankou \\ Belarus State Economic University \\ 220070, 26 Partizanski Ave., Minsk, Republic of Belarus \\ cross' $^{\text {ref }}$ http://dx.doi.org/10.5755/j01.ppaa.20.1.28389
}

\begin{abstract}
The system of external state audit reveals the potential for structural changes in terms of making effective management decisions that ensure the rational consumption of investment and other resources, taking into account the organizational and economic level of development. Based on the experience of foreign countries, it should be noted that in developed countries audit is the leading form of independent control. The purpose of this article is to determine the role of external public audit in ensuring the financial stability of the budgets of developing countries. To assess the financial stability of budgets, traditional methodological approaches, i.e. the analysis of absolute indicators and analysis of relative coefficients are used. In the study, financial stability was examined in the context of the possibility of evaluating the state audit of the budgets of developing countries for all expenses of the republican budget without raising the level of public debt. As a result of consideration of the budgets of developing countries, the problems were identified and the directions for their solution were proposed. In addition, tools which allow not only assess the financial stability of the budget, but also determine recommendations for managerial impacts aimed at strengthening the state budget are proposed. Thus, conducting a state audit in order to increase financial stability will lead to an increase in the efficiency of public administration and to a greater alignment of mechanisms for implementing state programs and projects with strategic planning mechanisms.
\end{abstract}

Keywords: budget funds, budget system, state audit, state apparatus, budget sustainability

Raktažodžiai: biudžeto lèšos, biudžeto sistema, valstybès auditas, valstybès aparatas, biudžeto tvarumas 


\section{Introduction}

Based on the experience of foreign countries, it should be noted that in developed countries audit is the leading form of independent control. Despite the variety of forms and methods of state audit, the systematic adaptation of the highest audit bodies of different countries to general requirements has been strengthened. In addition, the main documents of international organizations of supreme bodies of state audit contain a thesis that takes into account national characteristics of management systems. Features of the formation of countries and their political systems have had a significant impact on the construction of appropriate management systems. The three main models of state audit are the Napoleonic, Westminster and Collegial models based on the assessment of trends in the historical aspects of the economic and political development of the state. The models of the supreme bodies of state audit in this area facilitate the analysis of the country's best practices and allow to analyze the possibility of extending this experience to the management systems of other countries.

In turn, in recent years, particular importance has been attached to issues of increasing the financial stability of budgets of various levels in foreign countries. The financial stability of budgets depends on many factors. Significant factors include the effectiveness of revenue and expense planning for the next financial year as well as the implementation of planned revenue and expense indicators, which increases the role of their analysis. Prevention of a deficit of budget funds, as well as the search for sources of coverage of the deficit in the event of its occurrence, are the main tasks of the authorities. In this connection, the significance of assessing the implementation of the regional budget is increasing not at the end of the financial year, but throughout the budget execution process during the year. Only a state audit increases the possibility of quality budget execution. The purpose of this article is to determine the role of external public audit in ensuring the financial stability of the budgets of developing countries. The novelty and scientific value of the research is determined by the fact that the system of external state audit reveals the potential for structural transformation in terms of making effective management decisions that ensure rational consumption of investment and other resources, taking into account the technical, technological and organizational and economic level of development.

\section{Literature Review}

In the scientific literature, various authors provide concepts of state audit. In many countries, state audit is defined as a risk management system that takes into account the shortcomings of the budget process and allows taking effective measures to address them and also solves the issues of stability of the state budget. According to Rogers and Kollewe (2013), the assessment of the external state audit of budgetary stability is carried out by studying special ratios based on the analysis of official budget statements. It is very important to develop a state audit in the field of developing assessments of the financial stability of budgets of various levels, which allows improving their balance and efficiency. Two most conceptual approaches to the issues of conducting state audit can be distinguished. A number of researchers believe that this type of state financial control is designed to evaluate not only the efficiency of spending state resources, but also the effectiveness of the executive authorities (Karabayev, 2018; Bukrieiev, 2019). According to Jacobson (2015), the main target setting of this type of audit should be aimed at analyzing and evaluating the effectiveness of the implementation by the authorities of the functions assigned to the state and involving the expenditure of the state budget. Franda (2006) believes that in the broad sense, the concept of "performance audit" includes two main elements, i.e., a comprehensive assessment of the activities of government bodies and an assessment of the efficient use of budget financial resources. According to Karabayev (2019) and Jeppesen (2019), in the framework of the performance audit, an important role is played by the assessment of the correct choice and clear formulation of the directions of the policy of public spending, their interrelation with the needs of society. 
Furthermore, it is suggested that the state financial audit includes the individual: state financial audit of a budget institution; state financial audit of business entities of state and communal ownership; audit of budget programs; audit of the implementation of local budgets (Zhupysheva et al., 2019). The institution of state audit is nothing more than one of the special mechanisms to ensure the legitimacy of power and confirm the legitimacy of its actions. That is, state audit directly contributes to the stability of political institutions and the socio-political situation as a whole (Makashina, 2010; Petrenko, 2018; Chernychko et al., 2018; Pigosh, 2020). Such an audit is a check by the authorized bodies of the activities of recipients of public funds, public authorities in order to determine the effectiveness of their use of public funds received to fulfill their functions and assigned tasks. It includes the following elements: verification of the effectiveness of the organization's use of public funds spent on achieving specific results; verification of the productivity of the organization's use of labour, financial and other resources in the process of production and other activities as well as the use of information systems and technologies; verification of the performance of the audited organization in fulfilling the tasks assigned to it, achieving actual results (in comparison with the planned indicators and taking into account the amount of resources allocated for this) (Sembiyeva et al., 2019; Karabayev and Sembiyeva, 2020).

\section{Methodology}

Currently, government bodies, investors and lenders are facing acute challenges in their attempt to increase the effectiveness of the regional budget system; the lack of transparent unified methods for determining the budgetary sustainability of the external state audit is part of the problem. In order to analyze fiscal sustainability, we propose that coefficients as indicators, i.e., relative indicators of the state of the budget, calculated as the ratio of absolute budget indicators to each other, should be used. The definition of indicators of fiscal sustainability could be based on the directions of use of funds and sources of financing, i.e., based on the grouping of expenses and budget revenues, asset items and liabilities of the budget balance. The methodology for assessing the budgetary sustainability of the external state audit should meet the requirement of ease of use and be linked to the availability of source data. Hence, to assess the financial stability of budgets, traditional methodological approaches, the analysis of absolute indicators and analysis of relative coefficients, were used. As calculation methods, horizontal and vertical comparison, grouping, aggregation, chain substitution methods, factor analysis methods, methods of absolute and relative differences, methods of economic and mathematical modeling were used. There are various methods to determine the financial condition of budgets. In this article, we propose a methodological approach to assessing the level of financial stability without taking into account other aspects of the financial condition, such as liquidity, balance, social orientation, etc. In developing the methodology, methodological approaches of various authors were used. For the purpose of study, developing countries such as China, Brazil, Kyrgyzstan, Ukraine, Russia were considered.

The proposed methodology for assessing the financial stability of budgets will allow not only to analyze the state of municipal finances, but also to assess budget resources and the results of their use, identify budget threats and risks, and develop measures to neutralize them (Serikova et al., 2020; Igibayeva et al., 2020). For example, according to Alesina, Favero and Giavazzi (2018), the scientific significance of the concept of financial stability of the region's budget consists in identifying three key components: 1) "budget efficiency" from the position of fulfilling planned budgetary obligations; 2) "financial independence of the budget" from the position of security of the budget with tax and non-tax revenues, the formation and execution of the budget without increasing public debt; 3) "balance of the budget", both from the position of the correlation of budget items, and from the position of the availability of financial reserves to cover events unforeseen by the budget that ensure the stability of the financial system to risk events. Based on the allocation of the above-mentioned three key areas of analysis, we developed a methodological approach to a comprehensive assessment of the financial stability of the budget. 


\section{Results and Discussion}

The methodology for the analysis of budget indicators, which is traditionally used by public authorities, considers budget parameters as a percentage of GDP and assesses the budget deficit upon its execution. According to the data of the International Monetary Fund (IMF), the largest share of state revenues in GDP for 2018 among the analyzed countries was Ukraine (38.5\%), the smallest to China (23.6\%) (Table 1).

Table 1. Parameters of budget systems of countries in a number of developing countries, \% of GDP

\begin{tabular}{|c|c|c|c|c|c|c|c|c|c|}
\hline COUNTRY & INDICATOR & 2011 & 2012 & 2013 & 2014 & 2015 & 2016 & 2017 & 2018 \\
\hline \multirow[t]{3}{*}{ China } & Income & 22.6 & 22.6 & 22.1 & 22.3 & 22.7 & 23.0 & 23.3 & 23.6 \\
\hline & Costs & 23.9 & 24.8 & 24.2 & 24.0 & 23.8 & 23.5 & 23.2 & 22.8 \\
\hline & Deficit & -1.3 & -2.2 & -2.1 & -1.8 & -1.1 & -0.6 & 0.1 & 0.7 \\
\hline \multirow[t]{3}{*}{ Brasil } & Income & 36.6 & 37.2 & 37.0 & 36.9 & 37.2 & 37.1 & 37.2 & 37.3 \\
\hline & Costs & 39.1 & 40.0 & 38.2 & 38.6 & 39.0 & 38.7 & 38.7 & 38.7 \\
\hline & Deficit & -2.5 & -2.8 & -1.2 & -1.7 & -1.8 & -1.6 & -1.5 & -1.4 \\
\hline \multirow[t]{3}{*}{ Kyrgyzstan } & Income & 36.6 & 38.2 & 37.7 & 37.6 & 37.4 & 37.3 & 37.2 & 37.2 \\
\hline & Costs & 39.0 & 40.3 & 39.8 & 38.9 & 38.6 & 38.3 & 38.2 & 38.1 \\
\hline & Deficit & -2.4 & -2.1 & -2.1 & -1.3 & -1.1 & -1.0 & -0.9 & -0.9 \\
\hline \multirow[t]{3}{*}{ Ukraine } & Income & 42.9 & 44.6 & 43.5 & 41.5 & 40.8 & 40.3 & 39.4 & 38.5 \\
\hline & Costs & 45.6 & 49.3 & 48.0 & 46.9 & 45.0 & 43.8 & 42.9 & 41.9 \\
\hline & Deficit & -2.8 & -4.6 & -4.5 & -5.4 & -4.2 & -3.5 & -3.4 & -3.4 \\
\hline
\end{tabular}

Source: compiled by the authors based on the data of International Monetary Fund (2019).

According to statistics, the share of government spending in GDP in developing countries is declining. This is due to a slower pace than for the share of state revenues, which led to an increase in the state budget deficit in 2018. One of the reasons for this state of affairs is the fact that in the precrisis years, the growth rate of state revenues outstripped the growth rate of the market sectors of the economy, which was associated with the outstripping growth rates of energy prices (primarily oil), which made a significant contribution in budget-forming industries. Having considered the budgets of the analyzed countries, it is necessary to bring our approach to assessing the financial stability of the budget, which will be based on the use of coefficients in the analysis of the budget. However, as an alternative to standard ratios as indicators of the financial stability of the budget, we propose a system of indicators based on the key areas of analysis presented above (performance, financial independence, regional budget balance) and a regional budget score system (Table 2).

Table 2. Parameters of budget systems of countries in a number of developing countries, \% of GDP

\begin{tabular}{|c|c|c|}
\hline $\begin{array}{c}\text { DIRECTION OF } \\
\text { ASSESSMENT } \\
\end{array}$ & TYPES OF INDICATORS AND THEIR CALCULATION & $\begin{array}{l}\text { RECOMMENDED } \\
\text { VALUE }\end{array}$ \\
\hline \multicolumn{3}{|c|}{$\begin{array}{l}\text { 1. ESTIMATION OF THE EFFECTIVENESS OF THE REGION BUDGET FROM THE POSITION OF } \\
\text { EXECUTION OF THE PLANNED INCOME AND EXPENDITURE }\end{array}$} \\
\hline $\begin{array}{l}\text { 1.1. Evaluation of the execution } \\
\text { of approved planned budget } \\
\text { revenue assignments (used as } \\
\text { part of the standard budget } \\
\text { analysis approach). The goal is } \\
\text { to determine the completeness } \\
\text { of the planned revenues to the } \\
\text { regional budget. }\end{array}$ & $\begin{array}{l}\text { The percentage of budget revenues is determined by the } \\
\text { formula: } \\
\qquad P P_{R}=\frac{R_{1}}{R_{0}} \times 100 \text {, } \\
\text { where } \mathrm{PP}_{\mathrm{R}} \text { is the percentage of performance (percentage } \\
\text { performance) of budget revenues, in } \% \text {; } \\
\mathrm{R}_{1} \text { - budget revenues item upon execution, in tenge; }\end{array}$ & $100 \%$ \\
\hline
\end{tabular}




\begin{tabular}{|c|c|c|}
\hline $\begin{array}{c}\text { DIRECTION OF } \\
\text { ASSESSMENT }\end{array}$ & TYPES OF INDICATORS AND THEIR CALCULATION & $\begin{array}{l}\text { RECOMMENDED } \\
\text { VALUE } \\
\end{array}$ \\
\hline & $\begin{array}{l}\mathrm{R}_{0}-\text { budget revenues item for planned budget assignments, } \\
\text { in tenge. }\end{array}$ & \\
\hline $\begin{array}{l}\text { 1.2. Evaluation of the execution } \\
\text { of approved budget allocations } \\
\text { (used as part of the standard } \\
\text { budget analysis approach). The } \\
\text { goal is to determine the } \\
\text { completeness of fulfilling } \\
\text { budget obligations to recipients } \\
\text { of budget funds. }\end{array}$ & $\begin{array}{l}\text { The percentage of budget expenditures is determined by the } \\
\text { formula: } \\
\qquad P P_{E}=\frac{E_{1}}{E_{0}} \times 100 \text {, } \\
\text { where } P P_{\mathrm{E}} \text { is the percentage of performance (percentage } \\
\text { performance) of budget expenditures, in \%; } \\
\mathrm{E}_{1}-\text { budget expenditures item upon execution, in tenge; } \\
\mathrm{E}_{0}-\text { budget expenditures item for planned budget } \\
\text { assignments, in tenge. }\end{array}$ & $95 \%-100 \%$ \\
\hline $\begin{array}{l}\text { 1.3. The ratio of the execution of } \\
\text { revenues and expenses of the } \\
\text { budget (proposed by the } \\
\text { authors). The goal is to } \\
\text { determine the correlation } \\
\text { between budget execution by } \\
\text { income and expenses. }\end{array}$ & $\begin{array}{l}\text { The ratio of the execution of revenues and expenses of the } \\
\text { budget is determined by the formula: } \\
\qquad I_{R A E}=\frac{P P_{R}}{P P_{E}} \text {, } \\
\text { where } I_{R R E} \text { is the indicator of the ratio of execution of budget } \\
\text { expenditures and budget revenues. }\end{array}$ & $>1$ \\
\hline \multicolumn{3}{|c|}{ 2. ESTIMATION OF THE BALANCE OF THE REGIONAL BUDGET } \\
\hline $\begin{array}{l}\text { 2.1. The coefficient of balance } \\
\text { of the regional budget (proposed } \\
\text { by the authors). The goal is to } \\
\text { determine the sufficiency of } \\
\text { own budget revenues for } \\
\text { spending in accordance with the } \\
\text { approved budget assignment. }\end{array}$ & $\begin{array}{l}\text { The balance coefficient of the regional budget is determined } \\
\text { by the formula: } \\
\qquad I_{B R B}=\frac{R_{T}+R_{N T}}{\sum E}, \\
\text { where } \mathrm{I}_{\mathrm{BRB}} \text { is the coefficient of financial stability of the } \\
\text { regional budget (the stability indicator of the regional } \\
\text { budget). }\end{array}$ & $\geq 0.85$ \\
\hline $\begin{array}{l}\text { 2.2. The ratio of the deficit to the } \\
\text { revenues of the regional budget } \\
\text { excluding donations } \\
\text { (used in the framework of the } \\
\text { methodology of Makashina } \\
\text { (2010). The goal is to track the } \\
\text { established regulatory value of } \\
\text { the maximum allowable budget } \\
\text { deficit. }\end{array}$ & $\begin{array}{l}\text { The ratio of the deficit to the revenues of the regional budget } \\
\text { excluding gratuitous income is determined by the formula: } \\
I_{D I R}=\frac{R B D}{\sum E} \text {, } \\
\text { where } \mathrm{I}_{\mathrm{DIR}} \text { is the coefficient of the ratio of deficit to income } \\
\text { of the regional budget excluding gratuitous income } \\
\text { (Indicator of deficit-income relations of the regional budget } \\
\text { without donations); } \\
\text { RBD - regional budget deficit in the analyzed period, as the } \\
\text { difference between actual budget revenues and budget } \\
\text { expenditures (regional budget definition), in tenge. }\end{array}$ & $\geq 0$ \\
\hline
\end{tabular}


As a result of consideration of the budgets of developing countries, the following problems were identified and the following directions for their solution were proposed: 1) a high level of subsidized budgets (about 50\%) and a low level of own revenues; financial decentralization and improvement of the system of intergovernmental relations can be an option; 2) the problem of the influence of counter budget flows and insufficient revenues can be solved by increasing the revenue base of local budgets; 3) the lack of domestic funding can be corrected by raising funds through alternative sources; 4) the untimely settlements with the budget of legal entities and individuals engaged in entrepreneurial and other activities generating income necessitates the improvement of state control over them; 5) the decrease in tax payments due to the loss-making of enterprises involves the development of measures to stabilize the financial condition of local enterprises; 6) excessive financial support for unprofitable budget organizations of the national economy requires a transition to partial self-financing; 7) the limited independence of local authorities necessitates an increase in the powers of local authorities. The main problem in the regulation of local budget revenues is the presence of factors restricting the tax independence of local authorities.

We made a calculation based on a score and types of financial stability, based on data from countries such as the USA, Russia, Ukraine and Kyrgyzstan (Table 3). The ratio of budget revenues and expenses to all countries is within the normal range (IRRE> 1). For the timely determination of problems, a scorecard is needed. It is presented in Table 4.

Table 3. Model scoring financial stability of the regional budget

\begin{tabular}{|c|c|c|c|c|c|c|c|c|c|c|}
\hline $\begin{array}{l}\text { SUSTAINABILITY } \\
\text { TYPE }\end{array}$ & $\frac{a}{a}$ & 站 & $\frac{\underline{\alpha}}{\underline{\alpha}}$ & 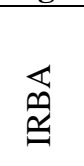 & $\begin{array}{l}\text { 잉 } \\
\text { 站 }\end{array}$ & 气ิ & $\frac{\vartheta}{\underline{\theta}}$ & $\stackrel{\widetilde{\bar{\theta}}}{\underline{\theta}}$ & $\frac{\alpha}{\underline{T}}$ & $\begin{array}{c}\text { AWARDING } \\
\text { POINTS FOR A } \\
\text { SINGLE } \\
\text { INDICATOR }\end{array}$ \\
\hline $\begin{array}{l}\text { Sustainable financial } \\
\text { position of the region }\end{array}$ & $>100$ & $<100$ & $>1$ & $>0.5$ & $<0.5$ & $<1$ & $>0.85$ & $\geq 0$ & 0.03 & 1 \\
\hline $\begin{array}{l}\text { Unsustainable financial } \\
\text { position of the region }\end{array}$ & 100 & 100 & 1 & $=0.5$ & $=0.5$ & 1 & $=0.85$ & $\geq-0.10$ & $\begin{array}{l}0<\mathrm{IPFR} \\
<0.03\end{array}$ & 0.5 \\
\hline $\begin{array}{l}\text { The critical financial } \\
\text { situation of the region }\end{array}$ & $<100$ & $>100$ & $<1$ & $<0.5$ & $>0.5$ & $>1$ & $<0.85$ & $<-0.10$ & $\begin{array}{l}<0 \\
>0.03\end{array}$ & 0 \\
\hline
\end{tabular}

Source: Authors.

Table 4. The results of the calculation of indicators of financial stability of the budgets of various countries as of 01/01/2019

\begin{tabular}{|c|c|c|c|c|c|c|c|c|c|}
\hline \multirow[t]{2}{*}{ INDICATORS } & \multirow{2}{*}{ 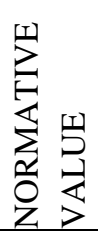 } & \multicolumn{2}{|c|}{ BRASIL } & \multicolumn{2}{|c|}{ UKRAINE } & \multicolumn{2}{|c|}{ KYRGYZSTAN } & \multicolumn{2}{|c|}{ CHINA } \\
\hline & & 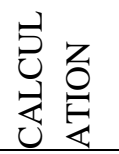 & $\begin{array}{l}\frac{1}{\alpha} \\
0 \\
U \\
\sim\end{array}$ & 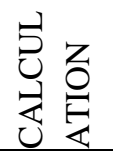 & $\begin{array}{l}\frac{1}{0} \\
0 \\
0 \\
0 \\
0\end{array}$ & 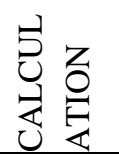 & $\begin{array}{l}\frac{1}{d} \\
\frac{1}{0} \\
\text { Un }\end{array}$ & 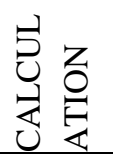 & $\begin{array}{l}\frac{1}{0} \\
0 \\
0 \\
0\end{array}$ \\
\hline PPr (percentage of budget revenues) & $\geq 100$ & 107.82 & 1.0 & 90.63 & 0.0 & 103.68 & 103.68 & 101.93 & 1.0 \\
\hline PPe (percentage of budget expenditures) & $\leq 100$ & 98.69 & 1.0 & 90.79 & 1.0 & 98.44 & 98.44 & 97.54 & 1.0 \\
\hline $\begin{array}{l}\text { Irre (ratio of the execution of budget } \\
\text { revenues and expenses) }\end{array}$ & $>1$ & 1.092 & 1.0 & 0.9998 & 0.0 & 1.053 & 1.053 & 1.045 & 1.0 \\
\hline $\begin{array}{l}\text { Irba (coefficient of autonomy of regional } \\
\text { budgets) }\end{array}$ & $>0.5$ & 0.98 & 1.0 & 0.60 & 1.0 & 0.49 & 0.49 & 0.88 & 1.0 \\
\hline $\begin{array}{l}\text { Ireor (ratio of expenses to own budget } \\
\text { revenues) }\end{array}$ & $\leq 0.5$ & 1.03 & 0.0 & 1.81 & 0.0 & 1.09 & 1.09 & 1.17 & 0.0 \\
\hline Icbd (budget debt coverage ratio) & $\leq 1$ & 0.24 & 1.0 & 0.55 & 0.0 & 0.09 & 0.09 & 0.42 & 1.0 \\
\hline Ibrb (budget balance ratio) & $\geq 0.85$ & 0.97 & 1.0 & -0.08 & 0.5 & 0.92 & 0.92 & 0.86 & 1.0 \\
\hline Idir (deficit-to-budget ratio) & $\geq 0.0$ & -0.01 & 0.5 & -0.08 & 0.5 & -0.04 & -0.04 & -0.03 & 0.5 \\
\hline Ipfr (reserve ratio) & 0.03 & 0.000 & 0.0 & 0.000 & 0.5 & 0.030 & 0.030 & 0.004 & 0.5 \\
\hline TOTAL POINTS & & \multicolumn{2}{|c|}{6.5} & \multicolumn{2}{|c|}{4.0} & \multicolumn{2}{|c|}{6.5} & \multicolumn{2}{|c|}{7.0} \\
\hline
\end{tabular}


Based on the results of calculating the financial stability of the above presented methods as well as on the basis of those indicators that have the greatest negative impact on the unsatisfactory results, we conclude that the main problem is the problem of subsidized budgets (autonomy of regional budgets). Given the calculation data, according to the results of the study, within the framework of the developed algorithm, management recommendations were proposed (Table 5).

Table 5. Parameters of budget systems of countries in a number of developing countries, \% of GDP

\begin{tabular}{|l|l|l|}
\hline $\begin{array}{l}\text { SUSTAINABILITY } \\
\text { TYPE }\end{array}$ & $\begin{array}{l}\text { THE ACTION OF REGIONAL } \\
\text { AUTHORITIES IN THE FRAMEWORK } \\
\text { OF THE ALGORITHM }\end{array}$ & $\begin{array}{l}\text { RECOMMENDED } \\
\text { SOLUTIONS }\end{array}$ \\
\hline $\begin{array}{l}\text { Sustainable fiscal } \\
\text { position }\end{array}$ & $\begin{array}{l}\text { Making managerial decisions to maintain } \\
\text { the financial stability of the budget }\end{array}$ & Maintaining current fiscal policy \\
\hline $\begin{array}{l}\text { Unstable financial } \\
\text { position of the budget }\end{array}$ & $\begin{array}{l}\text { 1. Identification of reasons for non- } \\
\text { compliance with recommended values. } \\
\text { 2. Adoption of managerial decisions } \\
\text { aimed at improving the financial stability } \\
\text { of the regional budget. }\end{array}$ & $\begin{array}{l}\text { 1. Identification of the reasons for not fulfilling } \\
\text { the budget revenues; the reasons for the lack of } \\
\text { owncome to cover budget expenditures; the } \\
\text { reasons for exceeding the allowable size of the } \\
\text { budget defit. } \\
\text { 2. Making management decisions based on the } \\
\text { results of studies; an increase in the share of } \\
\text { financial reserves in future budgets within the } \\
\text { state standard. }\end{array}$ \\
\hline
\end{tabular}

Source: Authors.

In order to increase the stability of the budget for conducting an external state audit, authors we propose using the method of assessing acceptable audit risk, according to which the level of this risk is determined by the following formula:

\section{$\mathrm{DAR}=\mathrm{IR} \times \mathrm{CR} \times \mathrm{DR}$}

where DAR is the acceptable audit risk (Desired Audit Risk), IR is the inherent risk (Inherent Risk), DR is the risk of failure to detect (Detection Risk).

When using this method, risk is perceived as a combination of two 2 risk factors: the factor of the existence of significant inaccuracies in the reporting of the control object; thea factor of possible non-detection of the above incorrect reporting by the inspecting staff and the formation in this connection of incorrect conclusions of the auditor. The risk assessment of the object of control has a direct impact on the frequency of its inspection: a higher risk assessment corresponds to a high frequency of inspections. When forming the plan of control activities of the body conducting the external state audit in the countries under consideration, the following calculation algorithm is used:

$$
\mathrm{O}=\mathrm{B}+\mathrm{CP} / 2+\mathrm{H} / 3 \text {, }
$$

where $\mathrm{O}$ - objects of control to be included in the plan of control activity; B - objects of control with a high degree of risk, $\mathrm{CP}$ - objects of control with an average degree of risk, $\mathrm{H}$ - objects of control with a low degree of risk.

In accordance with this algorithm, all objects of control are classified into three groups: with a high, medium and low degree of risk. Based on the classification results, the control plan of the external public audit body will include all objects of the first group (high risk), $50 \%$ of the objects of control of the second group (medium risk) and 30\% of the objects of the third group (low risk). In other words, the objects of the first group are subject to mandatory annual audit, the objects of the second group are subjected to external audit every two years, for objects from the third group the frequency of external audit is once every three years.

Thus, it is necessary to increase own revenues (tax and non-tax) by stimulating entrepreneurial activity, as individuals, becoming individual entrepreneurs, simultaneously become taxpayers once 
they become individual entrepreneurs, which leads to an increase in budget revenues. It is necessary to redirect budget funds to priority areas of activity, for example, the development of socio-cultural life, agro-ecotourism, the construction of entertainment and shopping centers, which, in turn, will lead to the efficient use of funds and the balance of budget revenues and expenses. And alsoImportantly, it is also necessary to develop measures to stabilize the financial condition of local enterprises and use local borrowing through financial market instruments (issue of securities). These measuresis will make it possible to finance local programs and capital-intensive projects and the funds received can be used to finance municipal services, road and housing construction, etc.).

\section{Conclusions}

1. A state audit on the basis of the model presented for assessing the budgets of developing countries determines the ability to carry out not only current financial activities by regional authorities, but also to cope with the debt burden in terms of paying off public debt form reserve funds, and increase the investment attractiveness of the region. In this connection, the analysis of financial stability of the regional budget is especially important. The assessment model presented and the algorithm for its application will allow us to divide the regions into three types, i.e., with an unstable, stable and crisis financial situation, highlight the most "problem" areas in financial planning and develop the necessary solutions.

2. The transition of the budget process to the principles of the effectiveness of the use of budget funds requires the creation of state audit mechanisms to determine the degree to which the goals, objectives and socio-economic results planned in strategic documents (primarily in the concept of long-term development) are achieved. Such mechanisms include, among other things, an audit of the effectiveness of the use of budgetary funds, which is widely used in state audits of foreign countries. Conducting a state audit in order to increase financial stability will lead to an increase in the efficiency of public administration and to a greater alignment of mechanisms for implementing state programs and projects with strategic planning mechanisms. Thus, the tools we propose allow not only to assess the financial stability of the budget, but also to determine recommendations for managerial impacts aimed at strengthening the state budget. One limitation of this study is that only a few developing countries have been analyzed. It should be noted that the most promising direction for further research on the subject matter is to analyze problematic aspects of the activities of supreme financial control authorities of countries, i.e., members of the Eurasian Economic Union.

\section{References}

1. Alesina, A., Favero, C., and Giavazzi, F. 2018. "Climbing out of debt". Finance \& Development, 55(1): 6-11.

2. Bukrieiev, E.V. 2019. "Management accounting - efficient tool of adaptive decisions acceptance in the conditions of unstable external environment of the enterprise". Scientific Bulletin of Mukachevo State University. Series "Economy", 1(11): 102-109.

3. Chernychko, T.V., Chernychko, S.F., and Rybchak, O.S. 2018. "Analysis of territorial regional development of retail trade network of Ukraine”. Scientific Bulletin of Mukachevo State University. Series “Economy”, 2(10): 120127.

4. Franda, M.F. 2006. The United Nations in the twenty-first century: Management and reform processes in a troubled organization. Lanham: Rowman \& Littlefield Publishers.

5. Igibayeva, Z., Kazhmukhametova, A., Beisenova, L., and Nikiforova, E. 2020. “Modern trends of Kazakhstan's internal state audit: the US and UK experience". Problems and Perspectives in Management, 18(2): 1-12.

6. International Monetary Fund. 2019. https://www.imf.org/en/Home [2020-11-18].

7. Jacobson, L. 2015. "Why don't more state auditors run for higher office?" https://www.governing.com/topics/elections/gov-why-dont-more-state-auditors-run-higher-office.html [2020-1118].

8. Jeppesen, K.K. 2019. "The role of auditing in the fight against corruption". British Accounting Review, 51(5): 100798.

9. Karabayev, A., and Sembiyeva, L. 2020. "Modern formation, development and becoming of an external state audit in the Republic of Kazakhstan". In Global Problems of Modernization of the National Economy. Materials of the IX International Scientific-Practical Conference, 317-325. 
10. Karabayev, E. 2018. "Methodological support for the formation of an external public audit system". In Modernization of the Economy of Kazakhstan - a Factor in the Stability of the Financial System of the State and the National Currency. Proceedings of the International Scientific and Practical Conference Dedicated to the 25th Anniversary of the National Currency of the Republic of Kazakhstan, November 9, 2018, Astana, Kazakhstan, 418421. Astana: L.N. Gumilyov Eurasian National University.

11. Karabayev, E. 2019. "Analysis of the activities of the Accounts Committee for control over the execution of the republican budget of the Republic of Kazakhstan". State Audit, 1: 42-47.

12. Makashina, O.V. 2010. "The mechanism for determining the financial condition of the territory". Audit and Financial Analysis, 3: 15-22.

13. Petrenko, N.O. 2018. Innovative policy of regional development of industry. Scientific Bulletin of Mukachevo State University. Series "Economy”, 2(10): 102-109.

14. Pigosh, V.A. 2020. "Code of corporate ethics as a tool for enterprise potential development". Scientific Bulletin of Mukachevo State University. Series “Economy”, 1(13): 104-107.

15. Rogers, S., and Kollewe, J. 2013. "Deficit, national debt and government borrowing - how has it changed since 1946?" https://www.theguardian.com/news/datablog/2010/oct/18/deficit-debt-government-borrowing-data [202011-18].

16. Sembiyeva, L.M., Tazhikenova, S.K., and Karabayev, E. 2019. "Experience in organizing external government auditing in foreign countries". State Audit, 4: 30-37.

17. Serikova, M., Sembiyeva, L., Karpitskaya, M., Beisenova, L., Alibekova, B., and Zhussupova, A. 2020. “The importance of innovative tools application in the development of state tax audit". Entrepreneurship and Sustainability Issues, 7(4): 2764-2783.

18. Zhupysheva, A.O., Makysh, S.B., Beisenova, R.R., Beisenova, L.Z., and Tazitdinova, R.M. 2019. "Criteria for auditing the efficiency of natural resource use. Example of the Karaganda region". Journal of Environmental Management and Tourism, 7(39): 1466-1477

Eldar B. Karabayev, Lyazzat M. Sembiyeva, Altai B. Zeinelgabdin, Lyazzat Z. Beisenova, Dzmitry A. Pankou

\section{Išorinio viešojo audito vaidmuo užtikrinant finansinị besivystančių šalių biudžetų stabilumą}

\section{Anotacija}

Valstybės išorinio audito sistemos analizė atskleidžia struktūrinių pokyčių potencialą priimant efektyvius valdymo sprendimus, užtikrinančius racionalų investicijų ir kitų išteklių vartojimą, atsižvelgiant $\mathfrak{i}$ organizacinị ir ekonominį išsivystymo lygị. Remiantis užsienio šalių patirtimi, reikia pažymėti, kad išsivysčiusiose šalyse auditas yra pagrindinė nepriklausomos kontrolès forma. Šio straipsnio tikslas yra nustatyti išorès viešojo audito vaidmenį užtikrinant besivystančių šalių biudžetų finansinị stabilumą. Biudžetų finansiniam stabilumui įvertinti naudojami tradiciniai metodologiniai metodai: absoliučių rodiklių analizė; santykinių koeficientų analizè. Tyrimo metu finansinis stabilumas buvo nagrinejjamas atsižvelgiant i galimybę ịvertinti besivystančių šalių biudžetų valstybinį auditą visoms šalies biudžeto išlaidoms nekeliant valstybės skolos lygio. Apsvarsčius besivystančių šalių biudžetus, buvo nustatytos problemos ir pasiūlytos jų sprendimo kryptys. Taip pat siūlomos priemonès, leidžiančios ne tik ịvertinti finansinį biudžeto stabilumą, bet ir nustatyti rekomendacijas dèl valdymo poveikio ir galimybès sustiprinti valstybės biudžetą. Taigi atlikus valstybinị auditą, siekiant padidinti finansinị stabilumą, padidès viešojo administravimo efektyvumas ir bus labiau suderinti valstybès programų ir projektų igyvendinimo mechanizmai su strateginio planavimo procesai.

Eldar B. Karabayev - PhD candidate at the Department of State Audit, L.N. Gumilyov Eurasian National University, Nur-Sultan, Republic of Kazakhstan.

E-mail: e.karabayev62@ust-hk.com.cn 
Lyazzat M. Sembiyeva - Full Doctor in Economics, Professor at the Department of State Audit, L.N. Gumilyov Eurasian National University, Nur-Sultan, Republic of Kazakhstan; Department of Financial Technology, South Ural State University, Chelyabinsk, Russian Federation.

E-mail: prof.sembiyeva@tanu.pro

Altai B. Zeinelgabdin - Full Doctor in Economics, Professor at the Institute of Management, Academy of Public Administration under the President of the Republic of Kazakhstan, Nur-Sultan, Republic of Kazakhstan.

E-mail: altai.zeinelgabdin@tanu.pro

Lyazzat Z. Beisenova - PhD in Economics, Associate Professor, Head of the Department of State Audit, L.N. Gumilyov Eurasian National University, Nur-Sultan, Republic of Kazakhstan.

E-mail: beisenova_lz@uohk.com.cn

Dzmitry A. Pankou - Full Doctor in Economics, Professor, Head of the Department of Accounting, Analysis and Audit in Sectors of the National Economy, Belarus State Economic University, Minsk, Republic of Belarus.

E-mail: da.pankou57@ust-hk.com.cn

Eldar B. Karabayev - Šalies audito katedros doktorantas, Nacionalinis L.N. Gumilyov Eurasian universitetas, Nur-Sultan, Kazakhstano respublika.

El. paštas: e.karabayev62@ust-hk.com.cn

Lyazzat M. Sembiyeva - Ekonomikos mokslų daktaras, Šalies audito katedros profesorius, Nacionalinis L.N. Gumilyov Eurasian universitetas, Nur-Sultan, Kazakhstano respublika; Finansiniu technologijų katedra, Pietų Uralo Universitetas, Čeliabinskas, Rusijos Federacija.

El. paštas: prof.sembiyeva@tanu.pro

Altai B. Zeinelgabdin - Ekonomikos mokslų daktaras, Vadybos instituto profesorius, Viešosios politikos akademija prie Kazachtano prezidento, Nur-Sultan, Kazakhstano respublika.

El. paštas: altai.zeinelgabdin@ @tanu.pro

Lyazzat Z. Beisenova - Ekonomikos mokslų daktarè, Docentė, Šalies Audito katedros vedèja, Nacionalinis L.N. Gumilyov Eurasian universitetas, Nur-Sultan, Kazakhstano respublika.

El. paštas: beisenova_lz@uohk.com.cn

Dzmitry A. Pankou - Ekonomikos mokslų daktaras, profesorius, Nacionalinės apskaitos, ekonominės analizès ir audito sektorių katedros vedejas, Baltarusijos valstybinis ekonomikos universitetas, Minskas, Baltarusijos republika.

El. paštas: da.pankou57@ust-hk.com.cn 